\title{
Canterbury farming: production, processing and farming systems
}

\author{
R.A.DYNES ${ }^{1}$, V.T. BURGGRAAF ${ }^{2}$, C.G. GOULTER ${ }^{1}$ and D.E. DALLEY ${ }^{3}$ \\ ${ }^{1}$ AgResearch Ltd, Lincoln Research Centre, PB 4749 Christchurch \\ ${ }^{2}$ AgResearch Ltd, Ruakura Research Centre, PB 3123, Hamilton \\ ${ }^{3}$ DairyNZ, Canterbury Agriculture and Science Centre, Lincoln
}

Robyn.Dynes@agresearch.co.nz

\section{Introduction}

Canterbury is of great significance to New Zealand's agricultural production, with approximately $20 \%$ of its farmland. The Region is the largest in New Zealand (by Regional Council boundaries), with $3 \mathrm{~m}$ ha of agricultural and exotic forestry land. This includes $1.2 \mathrm{~m}$ ha of grassland and a similar area of tussock and danthonia that is farmed. The region consists of a diverse mix of intensive dairy, sheep and beef and cropping operations on the plains, to extensive sheep and beef farms on high country. Half of New Zealand's grain seed and fodder crop land is in Canterbury (212 000 ha) (Statistics New Zealand 2008). The effective integration of these farming systems continues to be a feature of Canterbury agriculture.

Since settlement Canterbury has experienced significant periods of land use change, driven by access to water for stock and irrigation, and by relative profitability of different land uses (Manhire 2010). This has in part been underpinned by technology from the steel plough to frozen meat to automated spray irrigation.

This paper reviews the farming systems of Canterbury, in relation to land use, inputs and production compared to national and regional averages.

\section{History of the farming systems of the Canterbury Plains}

Sheep farming was the cornerstone of the Canterbury economy following settlement in early 1850 s. By 1860 Canterbury had $3.1 \mathrm{~m}$ sheep ( $21 \%$ of the national flock) (McLauchlan 1981) producing wool, skins, hides, tallow, and potted and salted meat. Production from the large leasehold runs (Acland 1951) underpinned the New Zealand economy. At this time dairy farming was localised to areas around small towns close to market and possessing heavier soils and more reliable summer pasture production. Banks Peninsula being one of the first dairying areas, exporting butter and cheese in 1840s and 1850s (McLaughlin 1981).

The wheat boom, rural railways, shelter belts and the first water races for stock in 1870s-1880s facilitated early land use change. Smaller family and freehold intensive mixed livestock and cropping farming became profitable and the spread of the family farm was hastened by the breaking up of large freehold estates between 1890 and 1914. http://www.teara.govt. nz/en/canterbury-region/7.

By the time of the First World War, the family farm of between 130 and 260 ha was the norm on the plains. This decreased after the Second World War as some large properties were cut up by the government for returned servicemen.

Between the world wars, farm mechanisation, the use of lime, and improved pasture seeds, raised farm productivity. There was even greater progress in the 1950s and 1960s. "Canterbury lamb" remained one of the region's major products.

Canterbury dairying for the mid 1900s was divided into two markets - cream production - "factory supply" and liquid milk - "town supply" for local consumption. The basis of payment was different for these farm types with the factory supply farmers being paid on a cents $/ \mathrm{kg}$ milk fat basis while the town supply farmers were paid on a cents/litre basis. Until the late 1970s factory supply farms supplied cream to the Tai Tapu dairy factory on the South Western corner of Hagley Park. Many of these farms were mixed dairy and pig operations with the skim milk being used to feed the pigs. The advent of refrigerated tankers and changes

Figure 1 Livestock numbers in the Canterbury region from 1994 to 2009. From Statistics New Zealand. (http://www.stats.govt.nz/methods_and_services/ access-data/TableBuilder/agriculture-statistics. aspx)

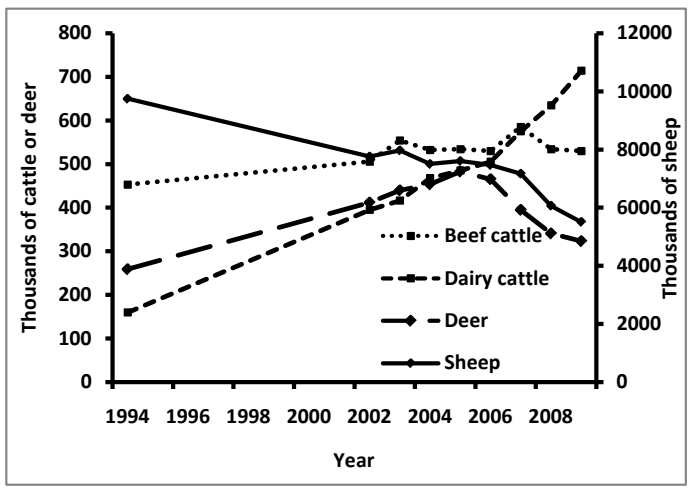


Table 1 Number of different farm types as at 30 June 2007. From Statistics New Zealand Agricultural Production Survey (2007). (http://www.stats.govt.nz/browse_for_stats/industry_sectors/agriculture-horticulture-forestry/2007-agriculturalcensus-tables/farm-counts.aspx).

\begin{tabular}{|c|c|c|c|c|c|c|}
\hline Region & Dairy & Beef & Sheep & $\begin{array}{c}\text { Sheep and } \\
\text { beef }\end{array}$ & $\begin{array}{l}\text { Grain-sheep or } \\
\text { grain-beef }\end{array}$ & Mixed livestock \\
\hline Waikato & 4362 & 2481 & 585 & 297 & 12 & 201 \\
\hline Hawke's Bay & 111 & 726 & 843 & 216 & 3 & 36 \\
\hline Taranaki & 1851 & 585 & 213 & 75 & 0 & 63 \\
\hline Manawatu- Wanganui & 900 & 1242 & 1794 & 324 & 15 & 117 \\
\hline Canterbury & 858 & 1551 & 2220 & 390 & 201 & 291 \\
\hline Otago & 357 & 390 & 1605 & 147 & 18 & 90 \\
\hline Southland & 672 & 222 & 2004 & 90 & 12 & 66 \\
\hline Total & 12084 & 12825 & 10956 & 2082 & 276 & 1230 \\
\hline
\end{tabular}

Table 2 Land able to be irrigated (ha) by region to year end 30 June 2007. From Statistics New Zealand agricultural production census.

\begin{tabular}{|c|c|c|c|c|c|}
\hline Region & Total area & Flood systems & Spray systems & Micro systems & System not stated \\
\hline Northland & 8714 & - & 5154 & 2430 & 1057 \\
\hline Auckland & 6256 & 29 & 4880 & 880 & 630 \\
\hline Waikato & 16578 & 914 & 14027 & 908 & 1943 \\
\hline Bay of Plenty & 9986 & - & 6527 & 2523 & 1551 \\
\hline Gisborne & 2345 & - & 1364 & 819 & - \\
\hline Hawke's Bay & 25165 & 413 & 17318 & 6887 & 1733 \\
\hline Taranaki & 3414 & 303 & 2764 & 134 & - \\
\hline $\begin{array}{l}\text { Manawatu-Wan- } \\
\text { ganui }\end{array}$ & 11730 & 152 & 9007 & 361 & 2629 \\
\hline Wellington & 12936 & 441 & 10891 & 1087 & 972 \\
\hline North Island & 97126 & 2814 & 71932 & 16028 & 11130 \\
\hline Tasman & 10712 & - & 6152 & 4052 & 902 \\
\hline Nelson & 342 & - & 260 & - & - \\
\hline Marlborough & 26669 & 623 & 13106 & 13408 & 1748 \\
\hline West Coast & 560 & - & 586 & - & - \\
\hline Canterbury & 385271 & 64386 & 313710 & 5734 & 13237 \\
\hline Otago & 91078 & 41986 & 44706 & 2330 & 6474 \\
\hline Southland & 7537 & 1011 & 6251 & 15 & 1065 \\
\hline South Island & 522168 & 108103 & 384773 & 25629 & 23524 \\
\hline New Zealand & 619293 & 110917 & 456705 & 41657 & 34653 \\
\hline
\end{tabular}

Figure 2 Proportion of total number of employees in the agricultural sector within Canterbury (Manhire, 2010).

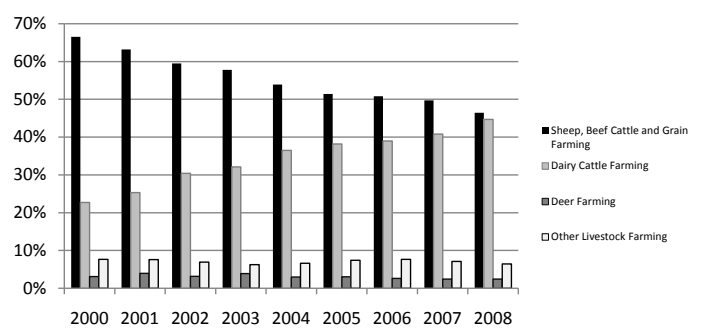

in regulations associated with mixing dairy and pig farming rapidly led to specialist dairy farms. The "town supply" farms were dominated by HolsteinFriesian stud farms in the Rangiora, Fernside, Lincoln, Tai Tapu and Greenpark areas of the plains. Large-scale milk processing for commodity products (e.g. whole milk powder) moved out of central Christchurch to the Clandeboye factory site in South Canterbury during the 1990s.

\section{Farming systems today}

The pattern of land use change has continued in Canterbury. Between 2002 and 2007 there was a 3.2\% 
increase in the area in grassland (39 $870 \mathrm{ha}$ ). This is probably from the development of tussock/danthonia which reduced by $8.8 \%$ (120 349 ha) during this period. Cropping area decreased by $6 \%$, while horticultural land increased by 29\% (3 631 ha) (Manhire 2010).

\section{Farm type and stock numbers}

In the last 10 years there has been a large number of sheep and mixed cropping farms converted to dairying on the Canterbury Plains, with an increased area under irrigation. Canterbury now has approximately 700000 dairy cows (Fig. 1), increasing from $5 \%$ to $15 \%$ of the national herd between 1994 and 2009. There are also 530000 beef cattle, 320000 deer, and sheep numbers have declined from 9.7 to 5.5 million (Fig. 1). Ewe numbers have fallen $29 \%$ while lamb numbers have fallen only $20 \%$ as a result of improvements in lambing $\%$ and lamb survival. These animals currently comprise 13,28 and $17 \%$ of the national total, respectively. Changes in stock numbers follow the general trend for New Zealand.

The predominant farm type in Canterbury is still sheep farming, followed by beef, then dairy, and then mixed enterprises (Table 1). Canterbury also has a significant number of farms incorporating grain production into their systems.

\section{Feed supply, irrigation and fertiliser}

Pasture yields on research stations on the Canterbury Plains average approximately $9 \mathrm{t} \mathrm{DM} / \mathrm{ha}$ for dryland and $18 \mathrm{t} \mathrm{DM} /$ ha under irrigation, compared to 15 to $18 \mathrm{t}$ $\mathrm{DM} / \mathrm{ha}$ on North Island research stations, and $14 \mathrm{t} \mathrm{DM/}$ ha for Southland (Clark et al. 2007). Pasture yields of over $22 \mathrm{t} \mathrm{DM} / \mathrm{ha}$ are reported for individual paddocks on the Lincoln University dairy farm (www.siddc.org. $\mathrm{nz})$.

Aerial topdressing of superphosphate fertiliser to hill country areas greatly improved the species grown and also provided large increases in pasture production. Topdressing technology began in 1949 and by 1958, approximately half the fertiliser that was used was applied from the air (Sheppard 1993). The amount and types of fertiliser in Canterbury has increased dramatically since the early days of topdressing; in 2008, approximately 170000 tonnes of $\mathrm{N}$ fertiliser, and 226000 tonnes of P fertiliser were applied in Canterbury (Statistics New Zealand 2008).

Over half of the New Zealand land area under irrigation is in Canterbury (Table 2). This has moved from predominantly border-dyke irrigation to $80 \%$ as spray systems. A recent survey (Payne \& Stevens 2010) of Canterbury dairy farmers showed water use efficiency has improved, with $81 \%$ of respondents having made changes to improve the efficiency of their system.

\section{Sheep and beef production}

High country farming in Canterbury is based on Merino sheep and fine wool production $(17-21 \mu \mathrm{m})$, with on average $4.6 \mathrm{~kg}$ of wool harvested per stock unit. High country farming has been based largely on tussock grasslands and semi-improved pasture. In recent years irrigation on lowlands has led to an increasing focus on lamb production. Average lambing percentage remains low (Table 3), however, top performing properties are weaning $125 \%$. These Merino lambs are commonly finished at 11-13 months of age, targeting the early season slaughter premiums.

Canterbury hill country sheep and beef farms have a proportion of land that is in tussock or too steep to be cultivated by wheeled tractors. They run fine wool, mid-micron or crossbred sheep according to the class of country and farmer preference. These enterprises are a combination of breeding flocks and herds and store stock. There is a significant range in performance on these properties, in part reflecting the ratio of easier to harder country (Table 3 ). These properties are on average 1400 ha in size running 4 su/ha with a lambing percentage of $110-130 \%$.

Breeding and finishing sheep and beef property data (Table 3) represents 1555 finishing breeding farms in coastal Marlborough and Canterbury. Farms are located on the dry downs and plains, in irrigated areas, and in the higher rainfall upper plains. Farms in the region range in farm size, stocking rate, stock class, and performance. The farms in the model have an average effective area of 369 hectares and normally run 9-10 stock units per effective hectare. Breeding ewe flocks with lamb finishing predominate, with cattle finishing and/or graziers on many properties. Some farmers also derive income from cash cropping, deer, beef breeding cows, lamb finishing, farm forestry, and off-farm sources. Cattle returns are calculated on a beef finishing policy.

Mixed cropping farms are a feature of the Canterbury plains. These farms are generally more than $75 \%$ irrigated or are located in usually reliable rainfall areas. Most grow a combination of crops integrated with stock. Currently cropping is more than $70 \%$ of farm income (Table 3). Current land use on an individual property is a function of a range of factors including farmer preferences, relative profitability, balancing risk and availability of resources. These properties are running on average 2000 stock units and range of crops (Table 4)

\section{Integrated farm systems}

The integration of farming systems is a feature of 
Table 3 Average farm systems production and financial statistics for 2009-2010. Source Beef + Lamb NZ economic service.

\begin{tabular}{lcccc}
\hline & Mixed & Finishing & Hill & High \\
& $2009 / 2010$ & $2009 / 2010$ & $2009 / 2010$ & 1773 \\
\hline Farm size (effective area, ha) & 356 & 410 & 6180 & 10980 \\
Total (SU) & 2044 & 3434 & 10404 \\
Stock units/ha & 5.7 & 8.4 & 3.5 & 0.9 \\
Ratio stock units: sheep:cattle:deer & $35: 13: 1$ & $28: 14: 1$ & $1336: 689: 1$ & $29: 9: 1$ \\
Lambing \% & 145.1 & 137.2 & 123.8 & 105.3 \\
Calving \% & 80 & 87.9 & 84.8 & 85.8 \\
Fawning \% & NA & 75 & 68 & 84.8 \\
Crop as a \% of income & 0.7 & 0.0 & 0.0 & 0.0 \\
Total meat/ha (\$) & 419.89 & 600.66 & 176.41 & 31.93 \\
Total wool/ha (\$) & 37.64 & 69.76 & 33.29 & 26.49 \\
Total other/ha (\$) & 1832.86 & 90 & 6.54 & 2.92 \\
EFS/ha (\$) & 225.7 & -11.95 & 6.36 & 1.79 \\
\hline
\end{tabular}

Table 4 Canterbury arable cropping model crop areas.

\begin{tabular}{lccc}
\hline Year ended 30 June & 2008/2009 (ha) & 2009/2010 (ha) & $2010 / 2011$ budget (ha) \\
\hline Crop & 83 & 84 & 82 \\
Wheat & 43 & 25 & 27 \\
Barley & 5 & 5 & 5 \\
Other cereals & 48 & 51 & 45 \\
Grass seeds & 16 & 21 & 17 \\
Clover seeds & 15 & 15 & 18 \\
Vegetable/brassica seeds & 4 & 11 & 14 \\
Other seeds & 14 & 21 & 20 \\
Pulses & 20 & 14 & 14 \\
Silage crops & 11 & 16 & 16 \\
Process/fresh vegetable crops & 259 & 263 & 258 \\
Total crop area & 300 & 300 & 300 \\
Effective area & 86 & 88 & 86 \\
Percent of effective area in crop & & & 30 \\
\hline
\end{tabular}

farming in Canterbury (Claridge 1972). This integration is both within the farm and between farms usually on a seasonal basis to balance feed production and maximise on-farm productivity.

Within the farm business unit, integration is with the arable and livestock components of the system. The land use on these properties can be dynamic and strongly influenced by relative profitability. As early as late 1800s John Grigg (Longbeach) and Duncan Cameron (Springfield) backed practical skills and foresight by moving into wheat on a large scale when the time was right then back strongly into sheep again when refrigeration was on horizon (McLaughlin 1981).
The ability and willingness to change emphasis to chase the most profitable land use has continued from these early days. However, along with land use flexibility is the capacity to integrate within these farming systems to maximise profitability of the system.

Cereals (average $45 \%$ of arable crops grown) underpin the mixed cropping farm, autumn/winter or spring (barley) crops are sown with average yields of 9.1 t/ha for wheat and 8.0 t/ha for barley in 2009/2010 season (MAF 2010). This flexibility in sowing date can balance the high cost of winter feed for stock and provides opportunities to sow spring crops of barley after feeding off winter forage crops. Crop stubbles are 
utilised by stock including ewes after weaning. The fast growing dairy industry has provided a strong market for cereal straw, a by-product of the seed industry that was previously burnt or returned to soil.

Small seed crops (20-25\% of crop), commonly ryegrass and clover sown in late summer/early autumn integrate well with early lambing systems (Scott 1982) providing high quality feed for stock from an initial grazing in early winter, then through spring. These crops are closed up by early November which makes management of spring surplus and therefore feed quality on the remaining pasture easier. Contracted rearing of dairy replacements are increasingly replacing breeding ewes and bought-in finishing lambs on these properties.

Ryegrass seed crops commonly produce $2000-3$ $800 \mathrm{~kg} / \mathrm{ha}$ for annual crops and $1500-3000 \mathrm{~kg} / \mathrm{ha}$ of ryegrass seed and 5 tonne of ryegrass straw while white clover crops produce $500-1000 \mathrm{~kg} / \mathrm{ha}$. This straw is a valuable winter fibre source, retained on the farm as a winter supplement with forage (brassica and fodder beet) crops or pastures or sold to dairy farmers as a high fibre supplement.

Vegetable and brassica seed crops are currently a profitable crop for many mixed cropping farmers; target yields depend very much on the crop and are between 200 and $2000 \mathrm{~kg} / \mathrm{ha}$. These crops commonly follow a pasture phase when low levels of disease and contamination can be achieved. The late harvest of these crops is well suited ahead of autumn sowing of wheat. Canterbury farmers produce $93 \%$ of New Zealand seed potato crop and approximately $40 \%$ of New Zealand total potato crop with 4300 ha (Statistics NZ 2008) for domestic and export table potatoes yielding 60-65 t/ha, processing crops yielding $60 \mathrm{t} / \mathrm{ha}$ and seed potatoes $25-$ $30 \mathrm{t} / \mathrm{ha}$.

Forage production for in situ grazing or ensiling is increasing in response to demand from an expanding dairy industry. High yields, with 10-15 tonnes of rape and 20-30 tonnes of fodder beet, now realistic targets for many farmers. Grazing revenue is increasing in importance with dairy cattle wintering and grazing of replacement stock, contributing on average $14 \%$ to net cash income (MAF 2010). Two years of poor cash flow and in some cases, high debt has led to ongoing conversion to dairy farming. In 2010 it is predicted that five to ten mixed cropping farms will fully convert to dairying (MAF 2010).

An increasing proportion of the traditional flat land sheep farming areas in Canterbury has partially (dairy support) or fully converted to dairy farming, following the adoption of spray irrigation and increased profitability from dairy production. These large tracts of prime land have historically purchased store lambs from hill and high country for finishing within the mixed cropping system. The increase in dairying and dairy support is likely to increase pressure on hill country areas. Hill country farmers must therefore adjust their farming policies to accommodate finishing their own lambs, this includes: using innovative summer greenfeed crops, optimum feeding of pregnant ewes, and best practice methods of internal parasite control. Competition for flat land in Canterbury has also been increased by urban sprawl of towns and cities, and an increase in the number of relatively non-productive lifestyle blocks (Goulter \& Fraser 2009).

Hill country and cropping/arable farms in Canterbury have also diversified into dairy support. These properties are used by the burgeoning Canterbury dairy industry to provide grazing for dairy replacements, and winter grazing for mature dairy cows, plus the provision of cows. They also provide various feed supplements such as grain, straw, vegetable processing by-products, maize, whole crop cereal and pasture silages. The decision to use locally grown supplements such as grain is influenced by many factors such as the current milksolids payout, global grain prices (New Zealand dollar, global demand, international and local growing conditions) and costs of substitute supplements such as Palm Kernel Expeller (Clark 2008).

The costs of grazing dairy stock on dairy support properties is dictated by many factors, such as: level of the dairy payout, crop prices, cash flow from traditional activities, and profit margins on lamb/sheep and beef operations (Brown 2010). These parameters have also been influential in the decision of farming policy changes from traditional farming systems to dairy support, as previously discussed.

The integration of the various support industries connected with dairy production in Canterbury has increased in recent years. This is mainly driven by the requirement for dairy farms to import high quality feeds onto their milking platform or graze animals off the milking platform over winter. Integrated farming systems based on sheep and beef sector in Canterbury appear to have decreased in recent years due to competition for prime land from both dairy conversion and urban sprawl. The integration of these diverse farming systems where all sectors are represented in the landscape may be a key to a sustainable future for Canterbury agriculture.

\section{Dairy production}

Dairy farming has expanded rapidly in Canterbury, however, future expansion into dryland areas is constrained by the availability of water for irrigation. Conversions are still continuing in the higher rainfall foothill areas of mid and south Canterbury. Dairy 
Table 5 Regional analysis of dairy farming supplement systems in 2007/08.

( $1=$ all pasture, self contained; $2=$ dry cow feed purchased; $3=$ feed purchased for dry cows and to extend lactation in autumn, $4=$ feed purchased for dry cows and to extend both ends of lactation, $5=$ feed purchased all year round). Number of farms responded in brackets (DairyBase Statistics).

\begin{tabular}{|c|c|c|c|c|c|}
\hline Region & \% System 1 & \% System 2 & \% System 3 & \% System 4 & \% System 5 \\
\hline Northland (34) & 18 & 47 & 32 & 3 & 0 \\
\hline Waikato (93) & 8 & 29 & 40 & 20 & 3 \\
\hline Bay of Plenty (25) & 12 & 28 & 28 & 28 & 4 \\
\hline Taranaki (34) & 18 & 44 & 26 & 9 & 3 \\
\hline Lower North Island (26) & 4 & 27 & 19 & 46 & 4 \\
\hline West Coast/Tasman (46) & 9 & 46 & 35 & 11 & 0 \\
\hline Marlborough/Canterbury (47) & 4 & 9 & 51 & 34 & 2 \\
\hline Otago/Southland (16) & 0 & 31 & 44 & 25 & 0 \\
\hline
\end{tabular}

Table 6 Regional analysis of average farm size, stocking rate and milk production for 2008/2009 and milk production for 2007/2008 and 2006/2007. From New Zealand Dairy Statistics (LIC, DairyNZ).

\begin{tabular}{|c|c|c|c|c|c|c|c|c|c|c|}
\hline Region & $\begin{array}{l}\text { Total } \\
\text { herds }\end{array}$ & $\begin{array}{l}\text { Farm size } \\
\text { (ha) }\end{array}$ & Herd size & $\begin{array}{c}\text { Cows per } \\
\text { ha }\end{array}$ & $\begin{array}{c}\mathrm{kg} \mathrm{MS} / \\
\text { cow 08/09 }\end{array}$ & $\begin{array}{c}\mathrm{kg} \mathrm{MS} / \mathrm{ha} \\
08 / 09\end{array}$ & $\begin{array}{c}\mathrm{kg} \mathrm{MS} / \\
\text { cow } 07 / 08\end{array}$ & $\begin{array}{c}\mathrm{kg} \mathrm{MS} / \mathrm{ha} \\
07 / 08\end{array}$ & $\begin{array}{c}\text { kg MS/ } \\
\text { cow } 06 / 07\end{array}$ & $\begin{array}{c}\mathrm{kg} \mathrm{MS} / \mathrm{ha} \\
06 / 07\end{array}$ \\
\hline Waikato & 3584 & 104 & 308 & 3.02 & 314 & 952 & 287 & 872 & 331 & 1002 \\
\hline Taranaki & 1770 & 95 & 269 & 2.86 & 335 & 962 & 299 & 857 & 323 & 925 \\
\hline North Canterbury & 616 & 221 & 723 & 3.28 & 364 & 1187 & 384 & 1259 & 383 & 1215 \\
\hline South Canterbury & 230 & 224 & 714 & 3.25 & 356 & 1158 & 376 & 1221 & 379 & 1232 \\
\hline Otago & 355 & 180 & 514 & 2.88 & 367 & 1053 & 368 & 1073 & 387 & 1096 \\
\hline Southland & 809 & 192 & 517 & 2.73 & 374 & 1017 & 371 & 1004 & 389 & 1049 \\
\hline New Zealand & 11618 & 131 & 366 & 2.83 & 355 & 1018 & 307 & 873 & 330 & 934 \\
\hline
\end{tabular}

Table 7 Annual livestock kill ('000) in Canterbury From Statistics New Zealand, Table reference LSS021AA.

\begin{tabular}{lccccccc}
\hline & Cows & Steers & Bulls & $\begin{array}{c}\text { Total All } \\
\text { Cattle }\end{array}$ & Lambs & Total All Sheep & Total Pigs \\
\hline 1989 & 26 & 41 & 14 & 150 & 6695 & 8204 & 233 \\
1999 & 35 & 82 & 9 & 265 & 6262 & 7124 & 366 \\
2009 & 100 & 99 & 23 & 431 & 4334 & 5009 & 400 \\
\hline
\end{tabular}

production in Canterbury is intensive, with large inputs of supplementary feed, irrigation and wintering cows off the milking platform. The majority of farms purchase feed for winter and to extend either one or both ends of lactation (Table 5). Herd size, stocking rate and milksolids production/ha are higher in Canterbury than in any other region (Table 6). The Lincoln University Dairy Farm, in developing a world-best practice farming system, runs 4.15 cows/ha produces $1700 \mathrm{~kg} \mathrm{MS} / \mathrm{ha}$ from pastures where more than 16 tonne of feed is eaten.

With irrigation, dairying expanded quickly in the 1990s in Canterbury, however, the impact on the region has been wider than land use change per se. North Island dairy farmers were attracted south by cheaper land and the opportunity to expand their dairying operations. Dairying has brought with it socially different work routines to those of the traditional community life. Long-established sheep and cropping families have sold up or converted to dairying, and share-milking has increased the movement of families in and out of districts (http://www.teara.govt.nz/en/canterburyregion/8). Dairy farming and the allied industries have had many positive impacts for Canterbury; the boost to rural employment has had positive impacts on the wider rural economy and regional towns and has provided a much needed boost to rural school rolls in many areas.

\section{Viticulture}

Canterbury has two major wine areas, on the plains close to Christchurch city and in the Waipara Valley in North Canterbury. Canterbury is New Zealand fourth largest wine region with 1800 ha in vines $(5 \%$ New Zealand total) which are dominated by Chardonnay and Pinot Noir (60\%) with Riesling and Sauvignon Blanc third and fourth, respectively (http://www.nzwine.com/ statistics). 


\section{Production and processing in Canterbury}

Flour mills were built in Ashburton and Christchurch in late 1800s during the first wheat boom and are still in operation today. The Canterbury Frozen Meat Company started slaughtering stock and freezing carcases at Belfast north of Christchurch in 1883, followed by works at Kaiapoi, Islington, Hornby and Fairton. Tanneries, wool scourers and soap factories were built at Woolston, while the woollen mills were build at Kaiapoi and Christchurch. By 1922 superphosphate was being manufactured at Hornby. These industries remain today although reduced stock numbers has combined with consolidation and rationalisation leading to fewer larger processing plants and only a single wool scour and tannery remain.

Canterbury dairy farming produced $215 \mathrm{M} \mathrm{kg}$ of milksolids in the 2008/2009 season (NZ Dairy Statistics 2008-2009). Fresh milk is transported from suppliers to processing plants throughout the South Island. Fonterra's Clandeboye site in South Canterbury is supplied by 865 farms and during peak production processes $12.4 \mathrm{~m}$ litres of milk (Fonterra 2010) per day. An increasing number of smaller companies process milk in Canterbury; these include Synlait Milk processing more than $300 \mathrm{M}$ litres of milk per year (Synlait 2010) and New Zealand Dairies.

Meat processing remains a significant processing industry in Canterbury. Despite a decline in total numbers of animals slaughtered in the last 20 years (Table 7). This in part reflects the change in land use with increased dairying Canterbury in turn leading to increasing numbers of cattle slaughtered and less lambs being finished. Interestingly competition for procurement of stock regularly means stock finished in Canterbury are trucked out of the region for slaughter.

\section{Agriculture and employment in Canterbury}

The Agriculture, Forestry and Fishing industry employed $8 \%$ of Canterbury workforce in 2006 , up $1 \%$ from 2001 and against the national trend of declining employment (-3\%) within this sector (Fig. 2). This growth is mostly likely attributed to the expansion of the more labour intensive dairy industry in the region. It should be noted that the manufacturing industry sector includes employment that is derived from agricultural production, namely meat, wool, dairy and forestry (Department of Labour 2007). Canterbury has several large slaughter or freezing works (Silver Fern Farms and Canterbury Meat Packers are the largest) which provide seasonal employment for many workers. Dairy manufacturing at Clandyboye (Fonterra), Studholme (New Zealand Dairies) and Dunsandel (Synlait) also provide a large number of jobs. A second Fonterra milk processing plant in Darfield, Canterbury has been proposed. Another milk processing competitor (New Zealand Milk Company) is also going through the consenting process to build a milk powder factory north of the Waitaki River.

The turnover rate of employees (worker replacement rate - measures the proportion of workers that change independent of job availability) in the agricultural sector remains high. Census data from 2006 shows that the agricultural sector had the third highest rate (11.9\%) of employee turnover behind the following sectors: accommodation, cafes and restaurants $(16.9 \%)$, and property and business services (14\%). Although Canterbury is below the national agricultural employment turnover rate of $12.5 \%$ (Department of Labour 2007), it is a common local complaint that it is difficult to recruit, train and retain good quality staff. The number of immigrant workers in the Canterbury region has increased greatly in the last decade to cover the shortfall in agricultural employment. The trends in agricultural employment between sectors and farming policies has changed dramatically and, not surprisingly, reflects the land use changes occurring in rural Canterbury. The proportion of total agricultural employees employed in the dairy industry in Canterbury has increased by $22 \%$ from 2001-2008, and a decrease was shown in the sheep, beef cattle and grain farming sector of 21\% (Fig. 2) (Manhire 2010).

\section{Conclusions}

The farming systems of Canterbury range from the extensive wool producing high country runs to intensive irrigated arable, pastoral and horticulture of the plains. From the earliest days the farmers of Canterbury have changed and adapted farming systems to maximise profitability of the farming systems. The availability of water for irrigation and more recently large scale spray irrigation has been a key to much of the land use change. Agricultural employment has increased in Canterbury recently, against the national trend, reflecting the impact of increased dairying. Processing in Canterbury has changed and consolidated over time reflecting changes in supply of livestock, wool and milk from the region. The integration of these diverse farming systems where all sectors are represented in the landscape may be the key to a sustainable future for Canterbury agriculture.

\section{ACKNOWLEDGEMENTS}

Dr Phil Rolston, Roger Henderson, Jude Henderson and John Morgan for comments on this manuscript. Beef + Lamb NZ for sheep and beef data. Funding from Foundation for Research, Science and Technology Rural Futures program is acknowledged. 


\section{REFERENCES}

Acland, L.G.D. 1951. The Early Canterbury Runs. Whitcome \& Tombs Ltd. Christchurch, New Zealand.

Brown, P. 2010. Herd the latest - Autumn 2010 e-newsletter. accessed from the World Wide Web: http://www.sidf.co.nz/Herd_The_Latest_Autumn. pdf

Claridge, J.H. 1972. Arable farm crops of New Zealand. The Department of Scientific and Industrial Research in association with A.H. \& A.W. Reed, Wellington, New Zealand.

Clark, D.A.; Caradus, J.R.; Monaghan, R.M.; Sharp, P.; Thorrold, B.S. 2007. Issues and options for future dairy farming in New Zealand. New Zealand Journal of Agricultural Research 50: 203-221.

Clark, D. 2008. Local Voice - Mid Canterbury Provincial newsletter. Federated Farmers of New Zealand. October 2008. Accessed from world wide web: http://www.fedfarm.org.nz/f601,23359/23359 Mid Canterbury Oct 08e.pdf

Department of Labour. 2007. Canterbury in-depth Regional Labour Market Report. Accessed from the World Wide Web: http://www.dol.govt.nz/ publications $/ \mathrm{lmr} /$ archive/aidr-07/canterbury/index. $\underline{\text { asp }}$

Fonterra. 2010. Fonterra Locations Clandeboye New Zealand. Accessed 15 August 2010 www.fonterra. com

Goulter, C.; Fraser, T. 2009. The future of lamb finishing: feed programmes and finishing policies. Proceedings of the Society of Sheep and Beef Cattle Veterinarians of the New Zealand Veterinary Association. Annual Seminar 2009, pp. 99-106.

Manhire, J. 2010. New Zealand pastoral production sheep and beef profiles. Report prepared for Rural Futures; Current state of the industries review. March 2010.

McLauchlan, G. 1981. The Farming of New Zealand: An Illustrated History of New Zealand Agriculture. Australia \& New Zealand Book Co Pty Ltd. Auckland.
Ministry of Agriculture and Forestry. 2010. Pastoral Monitoring 2010. Published by MAF Policy Wellington New Zealand.

Payne, T.A.; Stevens, D.R. 2010. Water water everywhere? Farmer responses to competition for water resources in Canterbury, New Zealand. Proceedings of the $4^{\text {th }}$ Australasian Dairy Science Symposium: 59-62.

Scott, W.A. 1982. Grass seed production. In: Pastures and Pasture Plants. (Ed.) Langer, R. H. M. Wellington, A. H. \& A. W. Reed.

Sheppard, R. 1993. New Zealand Agricultural Policy Change: Some effects. Discussion paper 135. Agribusiness and Economics Research Unit, Lincoln University, Canterbury.

Statistics New Zealand 2008. Agricultural Production Survey. $\quad$ http://www.stats.govt.nz/browse for stats/industry_sectors/agriculture-horticultureforestry/AgriculturalProduction_HOTPJun08final/ Commentary.aspx

Synlait. 2010. Synlait making more from milk-about us. Accessed 15 August 2010. www.synlaitmilk.com. 